\title{
Research on Teaching Reform of Animation Major Based on School-Enterprise Cooperation
}

\author{
Yuhui Su, Zongye Lu \\ Department of Art and Design, Guangxi Technological College of Machinery and Electricity, Nanning City, \\ Guangxi Province, 530007, China
}

Keywords: School-enterprise cooperation; Animation major; Teaching reform; Personnel training

\begin{abstract}
School-enterprise cooperation is a platform of talents training on implementing the combination of work study and animation, and the personnel training mode of school-enterprise cooperation is an effective way to train animation professionals. Based on the learning and practical experience of the author, this paper firstly analyzed the current situation of animation major education and the significance of school-enterprise cooperation in higher vocational colleges, and then analyzed the problems existing in school-enterprise cooperation, and finally put forward targeted solutions. This paper argued that school-enterprise cooperation is an effective mode of talent training. It can not only help enterprises to develop, but also greatly promote the development of animation major in higher vocational colleges.
\end{abstract}

\section{Introduction}

Animation industry is a special industry. There are different customer groups in different enterprises, and there are many differences among different technical means, different project management methods, different working processes, different design concepts and different corporate cultures, so that students who receive unified teaching can not immediately get the jobs. As a result, it will result in a large shortage of talent animation companies. However, as the main force in the training of practical talents, higher vocational colleges actively explore the mode of training talents, adhere to the cooperation between schools and enterprises and train high-quality application-oriented talents suited to the needs of enterprises. Particularly, school-enterprise cooperation and combining work with education have become important components of the teaching reform in higher vocational education, which is an important field of educational theory and practice at home and abroad.

\section{The Present Situation of Animation Major Education and the Significance of School -Enterprise Cooperation in Higher Vocational Colleges}

The present situation of animation major education in higher vocational colleges. First, the animation education and employability are decoupled to each other. Animation professional training and market are decoupled, so that education does not meet the needs of the market. At present, there are many creative animation films in the domestic competition, but this leads to graduation students incapable on design tasks, for which they are lack of market experience. There is a certain gap between animation education and students' employability after graduation. Second, the source of teachers is weak, which obviously embodies in professional teachers. Animation major is basically built from zero to one, so teachers are seriously inadequate. Many animation professional backbone teachers at universities graduated from the computer major with very good technical ability, but they are lack of creative abilities. Others graduated from the art major with good design ability, but they are lack of technical and creative abilities. They are lack of practical experience in animation production with seriously inadequate teaching experience, so the status of teachers seriously affected the quality and effectiveness of teaching. Thirdly, professional settings and curriculum are unreasonable. From the professional setting, it is lack of animation and 
management majors; from the curriculum setting, it emphases on animation technology courses, especially on computer design techniques, which ignores the humanities related to film and television courses. If we say that "strengthening the development of animation technology and deepening the study of animation theory" is the responsibility of ordinary colleges and universities, the higher vocational education should pay more attention to the cultivation of skills than the undergraduate education. For higher vocational colleges, they should have their own characteristics in the division of animation major and the relevant professional courses.

Significance of school-enterprise cooperation in animation major. China's animation education is currently a weak link in the training of animation talents, and is the biggest weakness of industrial innovation and industrial take-off. The strength of animation education itself is weaker than that of industry development. It is necessary to rely on a relatively weak animation education to bear the important task of exporting talents for now and future industry. Animation education does not carry out the initial investment, and relies solely on the institutions themselves is not allowed. The main task of the college and university is teaching, so it cannot monitor market demand and dynamics for the first time. School-enterprise cooperation can better let institutions receive the direction of animation development, shorten the distance between students and the market and better realize the open teaching of animation. To strength the school-enterprise cooperation is the only way to do a good job in animation and animation major development. Animation school-enterprise cooperation is based on the interactive mode of talent needs, and it is an effective form of interactive talents training between higher vocational colleges and animation enterprises. For enterprises that implement school-enterprise cooperation, they can solve the shortage of technical talents, which is conducive to improve the cultural quality and technical level of enterprise employees, speed up the pace of technological upgrading and establish a good social image of enterprises.

\section{Problems Encountered in the Process of School-Enterprise Cooperation}

Requirement on production technology. Different companies have different production requirements on project making. Especially in the stage of model production, the requirement of building simple model and precise model is greatly different, and the technical requirement is more comprehensive. Not only the skilled design software is used, but also the basic knowledge of architecture is required. For example, the production of digital city virtual scene roaming mode is larger, and the uses of the simple model are more with higher requirements on mapping; the number of surface model is strictly controlled. The construction of real estate animation and architectural renderings requires higher fineness of the building model.

Conflict between project making and teaching time arrangement. The feature of project making is heavy workload. A lot of manpower is needed during the building modeling phase, and the production cycle is short and often requires overtime work. However, the university conducts the academic education. In addition to the major courses, it also involves other non professional courses, so students have limited spare time. At the same time, due to the limited capacity of the studio, students entering three studios account for about two thirds of the total number of students in the studio, which will have an impact on the production schedule in the student oriented studio.

Periodic problem of the student services. Generally speaking, freshmen mainly learn basic courses, so they do not have the conditions to enter the studio. The students who enter the studio are mainly sophomores and juniors. They are trained to be skilled in project making, and then immediately enter the graduation practice. Higher vocational graduation practice is linked with employment. As the construction of animation production industry is not large in general, cooperative enterprises can only solve the employment problems of some students. Most of the students will choose to leave the studio into social practice. For enterprises, students in the studio time are relatively short, and students will leave after training. It is easy to appear in the future, and affects the stability of cooperation.

The problem on enthusiasm of students. Students entering the studio for internships must comply with the relevant rules and regulations formulated by the enterprise. They should have strict 
requirements for the production process and work schedule. The working process of enterprises is relatively simple. Students usually engaged in building model making. For a long time, students are prone to boredom, and it will affect job enthusiasm.

\section{Solutions and Measures for Solving Problems}

In view of the technical requirements, we mainly solve it by improving teaching measures. First of all, we must discuss with the enterprise on developing the animation design and production professional teaching plan. According to the actual work needs, we have to adjust the teaching course content. In addition, the teaching of knowledge covers current mainstream architectural animation application technology. At the same time, we should combine with the characteristics of the institute, and pay attention to the depth integration between computer technology and construction technology. We should increase some basic knowledge courses of agriculture aiming at conditions of using computer software for the professional students, including Building Construction, Building Decorative Material and Landscape Design. This has formed professional curriculum system with its own characteristics. Moreover, the main courses are arranged in one to two weeks training weeks. We strengthen the practical operation ability and consolidate the learning content through the combination of work and study teaching mode. Secondly, we should strengthen exchanges and cooperation with enterprises. In the teaching content, we should increase the typical case made in accordance with the different technical requirements of the cooperation of enterprises, so that students master the professional technology comprehensively. We cultivate the person, whom the companies needed. At the same time, we should make full use of the advantages of first-line technical resources of enterprises. The enterprise arrange regular training for students, so we need to hire technical personnel as part-time teachers, who will be responsible for training courses, graduation design and graduation practice and other practical teaching link. Aiming at the characteristics of fast updating of computer technology and generally young professional teachers, we should strengthen the construction of professional teaching staff and actively train teachers. According to the specific situation, we should formulate rules and regulations, and we should encourage professional teachers to cooperate with enterprises on production practice or technical part-time jobs, and always keep in touch with cutting-edge technologies. As a result, we can create excellent professional and technical team with an innovative spirit. Finally, we should change the single way for course grade assessment by teachers; in other words, course grades assessment should jointly assessed by teachers and enterprises on the performance evaluation of training courses (such as graduation design, graduation practice). This highlights the importance of practice teaching. Evaluation of enterprise and the teachers are accounted for fifty percent of the total score.

Solve the conflict between project making and teaching schedule. To solve this problem, we take countermeasures of regarding the students who enter the graduation design stage as main members at studio with flexible teaching methods. We integrate the actual project content into the teaching process of graduation project, and take the project completed by the students in the studio as the content of the graduation design course evaluation. For those who did not enter the studio, we take the forms of participating in the synchronous project. Our test standard is the finished work being adopted by the enterprise. This not only ensures the implementation of teaching links, but also ensures the normal operation of enterprise project making.

Solve the periodic problems of student services. We should emphasize the role of teachers, and pay attention to the learning situation of low grade students in software based teaching process. We should select outstanding students to enter the studio by taking both old and new ways. At the same time, we want to promote the students to learn, so that to solve the fault problem caused by more liquidity of the students.

Arouse students' enthusiasm for study. First of all, the instructor should manage the studio strictly according to the rules and regulations. At the same time, they should pay attention to communication with students with technical guidance. We should often arrange graduate members of the studio to carry out exchanges and discussions through experience. The studio members can understand the importance of participating in the actual project making and improve their 
professional skills and the future employment through the subtle form. Secondly, we should work together with the enterprise to make the studio reward standards according to the amount of work done and the appropriate piece with appropriate remuneration driven by economic interests, so that students get some work and improve the enthusiasm of participation.

\section{Summary}

Animation professionals training mode of school-enterprise cooperation is still in practice. Higher vocational colleges should give full play to their own advantages and characteristics, and strive to build animation personals training of the school-enterprise cooperation platform. After understanding the production process and requirements on an animation enterprise deeply, higher vocational colleges should adjust their teaching direction and teaching plan, and attach great importance to students' training in the front line. As a result, it will meet the needs of society and cultivate integrated application talents with a certain innovation ability, practical ability and skilled animation technology production.

\section{References}

[1] Ma Jun, Ceng Xiangjun, He Chunfang, Liang Qiao. Exploration of School-Enterprise Cooperation in Teaching Reform[J]. Journal of Electrical and Electronic Teaching, 2009, (02): 17-18.

[2] Gong Chang. Exploration of Practice Teaching Reform in Colleges and Universities Cooperation Mode[J]. Industry and Science and Technology Forum, 2016, (19): 138-139.

[3] Mr. Wang, Yang Simin. Research on Animation Teaching Mode in School-Enterprise Cooperation[J]. Journal of Wuyi College, 2014, (01): 68-70.

[4] Wu Liyun. Application of School-Enterprise Cooperation in the Construction of Animation Teaching Resources[J]. Computer Knowledge and Technology, 2011, (35): 9184-9185+9196.

[5] Wang Wenjin. Experiment and Reflection on the Teaching Reform of Deep Cooperation between School and Enterprise[J]. China Vocational and Technical Education, 2010, (32): 47-52.

[6] Kong Bin, Ma Jincai. Discussion on Teaching Reform under the Mode of School-Enterprise Cooperation and Combination of Work and Study[J]. journal of Ningxia University(Humanities and Social Sciences Edition), 2010, (03): 181-183. 